This article was downloaded by: [University of Auckland Library]

On: 15 February 2015, At: 06:08

Publisher: Routledge

Informa Ltd Registered in England and Wales Registered

Number: 1072954 Registered office: Mortimer House, 37-41 Mortimer Street, London W1T 3J H, UK

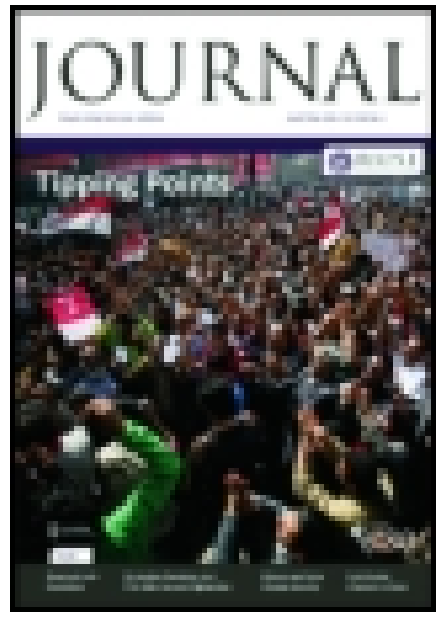

Royal United Services Institution. J ournal

Publication details, including instructions for authors and subscription information: http:// www. tandfonline.com/loi/ rusi 19

\title{
The Naval and Military Resources of the Colonies
}

Captain J. C. R. Colomb R. M.A. Published online: 11 Sep 2009.

To cite this article: Captain J . C. R. Colomb R. M. A. (1879) The Naval and Military Resources of the Colonies, Royal United Services Institution. J ournal, 23:101, 413-430, DOI: 10.1080/03071847909417109

To link to this article: http://

dx. doi.org/ 10.1080/03071847909417109

\section{PLEASE SCROLL DOWN FOR ARTICLE}

Taylor \& Francis makes every effort to ensure the accuracy of all the information (the "Content") contained in the publications on our platform. However, Taylor \& Francis, our agents, and our licensors make no representations or warranties whatsoever as to the accuracy, completeness, or suitability for any purpose of the Content. Any opinions 
and views expressed in this publication are the opinions and views of the authors, and are not the views of or endorsed by Taylor \& Francis. The accuracy of the Content should not be relied upon and should be independently verified with primary sources of information. Taylor and Francis shall not be liable for any losses, actions, claims, proceedings, demands, costs, expenses, damages, and other liabilities whatsoever or howsoever caused arising directly or indirectly in connection with, in relation to or arising out of the use of the Content.

This article may be used for research, teaching, and private study purposes. Any substantial or systematic reproduction, redistribution, reselling, loan, sub-licensing, systematic supply, or distribution in any form to anyone is expressly forbidden. Terms \& Conditions of access and use can be found at http://www.tandfonline.com/page/terms-andconditions 


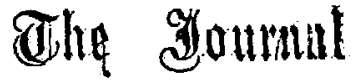 \\ OF TER \\ gounal alnited Sorvite anstitution.}
YOL. XXIII.
1879.
No. CI.

\section{LECTURE.}

Friday, March 28, 1879.

THOMIAS BRASSEY, Esq., M.P., \&c., \&c., in the Chair.

\section{THE NAVAL AND MIILITARY RESOURCES OF THE GOLONLES.}

\section{By Caprain J, C. R. Coloyb, R.M.A.}

Ix giving effect to the wish of the Conncil by reading a paper on this subject, I desire, in the first place, to point out the dificulty which limits the possibility of its full discussion here. Resources-especially of War-must be practically available, capable of actual, if not of immediate, application or development. Now, in our great Colonies, ${ }_{3}$ which offer the widest field for present inquiry, the possible development or the practical availability of such war resources as they possess rests with their own particular Legislatures.2 Thether those elements of war-power shall or shall not be developed; whether they shall or shall not be made available; whether, in short, they are or are not in the trne sense of the term "resources," are matters for their decision and not for this Institution to discuss. Therefore, the vital essence of the whole subject must here remain untouched. ${ }^{3}$ Though it bo not legitimate in this place to consider whether those things of which $I$ am about to speak are or are not therefore really and truly our naral and military "resources," we, as Officers of constitutional forces, must not be blind to constitutional facts. Those who turn wistful eyes towards Grenter Britain seeking for signs of naval and military help in that future no man can foretell, must not orerlook the tangle of difficulties we Englishmen-home and Colonial-hare made for ourselres in the present. The consolidation, development, or even the bare application of dormant or actual war force stored up in other Englands beyond sea are, from a naral and military point of view, purely theoretical questions based upon a complex variety of political assumptions. The carrying out of practical measures necessary for a common system of defence through the machinery of multitudinous

${ }^{1}$ Canada, Nerfoundland, New South Wales, Victoria, Qucenslaud, Tasmania, South Australia, New Zealand, and the Cupe.

2 Vide "Constitution of the Britannic Empire," Creasy ; "Furopean Colonies," Parne; "The English Constitution," Amos ; "The Colonial Office List," Offeial.

3 See speceh of the late Premier of South Australia, rol. xxi, No. 91, p. uBG, Journal.

roL. XxIII.

2 F 
Legislatures differently constituted is another and a wholly different matter. The one belongs to regions of naral and military scienceobviously for these reasons more or less speculative, the other is a stupendous problem, statesmen-of England, Canada, Australasia, and the Cape, \&ce.- lave to face.

In order to bring the subject placed in my hands to such a focus as shall render its brief consideration of the smallest practical ralue, it is, therefore, necessary to politically assume much. It must bo taken for granted that the Colonial naval and military resoureeswhatever they may be-are the common heritage and present common possession of the whole British race. That they are available, can be developed, and may be applied by an homogeneonsly constituted State. Finally, that these resources are to be regarded practically as factors of one great whole, the value of each factor being relative to its use and adaptability in one common Imperial plan of action in war.

From any other stand-point it would be a simple waste of time to inrestigate the present sources of resisting power-as regards external defence- of any one Colony taken by itself, for none isolated and alone could withistand the organized attack of any first-class Power. Volumes might be, indeed have been, written respecting the direct defence of the Canadian boundary, but the supporting strength of England is vital to the whole question. Any one of the rich, prosperous, and great Colonies in the Sonth Pacific might-under their present arrangements, and if single-handed - suffer severely from armed strength possessed even by such disorganized countries as Chili or Pera. The Cape could not, unaided, stand against the fleet and army of Brazil. ${ }^{2}$ Plainly, therefore, the naval and military resources of the Colonies can only be practically and usefully considered as

1 Nary of Chili : 2 ironclads, "Almiraute Cochrane," aud "Valparaiso." 10 small steamers.

Army of Chili : 1,200 eavalry and artillery. 2,000 infantry.

\section{3,200}

Nary of Peru : 6 ironclads, one being the notorious "Huascar."

6 steamers with armaments varying from 2 to 30 guns.

Srmy of Peru : 1,000 artillery.

1,200 cissalry.

5,600 infuntry.

5,400 gendarmerie.

13,200

2 Nary of Brazil : 18 ironclade, small

1 frigate

8 correttes

23 gunboats

7 transports

57

Army of Brazil : 3,250 artillery.

2,481 caralry.

9,864 infautry.

427 Statf and special corps.

16,055

Haring an aggregate of 177 guns, 10,000 horse-power. 
component parts of our great Imperial system. The object to be attained by that system being the security in war of the integrity of the dominions of the Queen, and the preserration of the manifold interests of the two hundred millions of human beings Her Majesty-by rarious Parliaments, Houses of Assembly, and Councils-rules.

I thus introduce the subject becanse, having been fortnnate enough to have elicited discussions in the press of the rarious Colonies, ${ }^{1}$ and baring elosely studied these and the opinions of eminent Colonial authorities, relative to Imperial Defence-I feel bound. to express my conriction that no good and mnch harm may come of disonssing this question concerning the Colonies without close regard to their constitntional status.

It is therefore due to this Institution to offer these preliminary remarks, and by doing so I hope to have made what is passing in my mind sufficiently clear without overstepping its laws. ${ }^{2}$

\section{IxTroductont.}

Colonies may be divided into three classes. ${ }^{3}$

1. Colonies Proper-Agricnltural, Pastoral, and Mining; such as Canada, Australasia, and the Cape.

2. Plantation Colonies-such as the West Indies, Ceylon, and Mauritius.

3. Military or trading settlements-such for example as Cyprus and the Fijis, Bermuda and the Straits Settlements, Mralta and the Falkland Isles, \&c., \&c.

Of these classes the first demands closest attention, for, as Heenan says, "the Colonists who form them become in process of time a " nation properly so called."'

Naral and military resources may be grouped under two heads, "raw and dereloped." Men, for example, are "raw materials," but the trained seamen and disciplined soldier are "developed resonrces." Coal and iron are "raw materials," the ironclad the perfect product of their development. It is therefore necessary to examine the nature of the raw materials before entering on questions of their present or possible future derelopment.

Raw and developed war resources may each be divided into tro branches of inquiry-men and material. The power of any people

1 Those articles published prior to 1877 can be seen in a book entitled "Colonial "Defence and Colonial Opinion," which will be found in the Rogal United Serrice Institution and Royal Colonial Institute Libraries.

2 A perusal of the folloring will explain more fully what is nccessarily left unsaid. The Jourzals of the "Rojal Colonial Institute" 1870-79; Froude's "Short Studies on Qreat Subjects;" articles in the "Nineteenth Century," by Sir Julius Vogel, and Sir F. Dincks, and in "Fraser's Magazine," 1878, hy Baden Powell, "Imperial Federation" by $F$. Foung. Sco also the articlo in the last Christmas number of "Vanity Fair," by the Duke of Manchester, and the conclud. ing chapter in Trilson's "Resourees of MIodern Nations," \&c., \&c.

3 I borrow this classification from a most raluable paper on "The Colonial and "Indian Trade," by Dr. Forbes Watson, vide "Journal Royal Colonial Institute," rol. ix.

"Quoted in Creasy's "Constitution of the Britannic Empire." 
to preserve by force their own possessions and their own freedom is a question of relative numbers and distinctive characteristics of mees. The possession of material resources, howerer great, may in war prove a curse instead of a blessing to any people too numerically weak, or too numerously neglectful to prepare to turn them readily to organized account for purposes of self-preservation. Hence the second placeunder ench hend-is here given to material resources. Consideratious concerning naval and military resources of the Colonies, I therefore take in the foregoing order, and venture to remind you it is impossible to do more than hastily point to the most prominent features of so buge a subject.

\section{MIEX.}

Table I shows the distribution of population in Colonies Proper. ${ }^{1}$ It will be seen that the aggregate population of the three great groups of Colonies is about eight millions, but the valne of the war resources, apparently offered by these figures, must be qualified by reference to the various races swelling the total. The Aborigines of $\mathrm{New}$ Zealand are not included, nor hare I taken account of the 100,000 Indians in Canada, nor of the 30,000 Chinese computed to have recently settled down at the gold-fields of Queensland. Withent, therefore, taking these into account, it will be seen that from the total aggregate population I have named, some one and a lalf millions must be deducted. I produce this offset of one and a balf millions from the total apparent numerical resources not as a precise statistical statcment, but as a fair substantial protest against forming lasty conclusions as to Military Colonial resources from fignres only. Besides nom-Europeans so deducted, it must also be borne in mind that the German element in the Colonies is considerable, and that a German, until a naturalized British subject, can hardly be counted as a raw material of British war resourees.

It is obriously impossible to enter further into details, bat I would point out that, after making reasonable deductions, the aggregate resources offered by British population of the three great groups of Colonies Proper-if estimated $b_{y}$ numbers-are more than three times those of Denmark, nearly double those of Portugal, and greater than those of Belginm. Canada in this respect bears fair comparison with the Netherlands, and Australasia with Switzerland. The ratio of increase of population of our Colonies cannot, however, be compared to any country of the Old World; Canada's population, for example, has increased some sevenfold in fifty years, and about doubled within the last five-and-twenty jears. The aggregate population of Colonies in Australasia has more than doubled in the last sixteen years, and is now about seventeen times what it was when Her Mrajesty began to reign.

1 The tables in appendices particularly concerning the Colonics must not be accepted as perfectly accuratc; though some trouble to make them sufficiently correct has been taken. A carcful examination of and comparison between the rarious sources of published information, home and Colonial, mill show the difficulties of obtaining perfeet accuracy at present. 
It must not, howerer, bo forgotten that numerical strength of population is-as an element of war resources-directly affected by refereuco to the territorial arca over which distributed. Now there are some 389 persons to every squaro mile in England and Wales, while in Australasian Colonies, the most densely populated, Victoria, has but 10 to the square mile; and the least, Western Australia, but one individual to every 38 square miles.

In Canada, a population about equal to that of London is distributed over an area half as big again $n$ s that of Russin in Europe.

In riewing population as a raw material of war resources, it is to bo observed that emigration from theso islands to a foreign territory represents so much present loss of war-power to ns, and an incaleulable increasing gain of war-power in the future to a possible enemy. ${ }^{1}$ The transfer of population from one part of the Einpire to another merely raries the distribution of this element of strength, and such redistribution mas-if utilized-be of incstimable military benefit in war. The pale-faced artizan, born, bred, and working in the foetid atmosphere of an overerowded manufacturing town nt home, is a very inferior " $\mathrm{mw}$ "matorial" of war resources - to the hardy Englishman labouring by the shores of Winnipeg, the baaks of the Murray or the Clatha, or on his "elaim" in Griqualand West. The historian Froude has so eloquently and forcibly written on this subject that further general remark is needless. Some rery striking passages from his "Short "Studies on Great Subjects" will be found quoted in Mr. Brassey's paper in the Journal of this Institution.2 It is, however, proper here to call attention to the opinion of a military authority. "The " Cavadians posscss," says Lientenant-General Sir Selby Smyth, "in "a marked degree, qualities to make excellent soldiers, being both "hardy and industrious, used to rongh life, ensily subjected to dis"cipline, and willing to submit to necessary authority. . . . There "are no better soldiers than Canada can produce."3 Turning our eyes towards these islands, it must be acknowledged that manufacturingr progress at home is rapidly absorbing rural populations, and shrinking the recruiting area which, from natural causes, provides the best raw material of military force. It is calculated our home population will amount in 76 Jenrs from this to some sixty millions, nearly donble what it is now. We may therefore expect the quality of raw material fearly offered by home recruiting fields to diminish rather than to increase with numbers; while in our Colonies it is both in quantity

1 During the 25 years ending 31st December, 1877, upwards of 4,000,000 persons (of British origin) emigrated from the United Kingdom, of which $2,700,000,-a$ number greater than the present tatul population of Switzerland, went to the United States. In 1877 the emigration $\pi 23$ as follows :-

45,000 to United States.

30,000 to Australasia.

7,000 to Cannda.

11,000 to all other places.

These figures are in round numbers for illustration of principles.

2 See "A Colonial Naral Reserre," by 'T. Brasses, JL.P., rol. xxii, No. 95, "Journal " of the Rosal United Service Institution."

3 Sce Official Report on "The State of Jilitin of Canada," 1877. 
and quality increasing erery year at a rate difficult to accurately estimate. It has, however, been calculated that, in some 21 years from this date, the aggregato population of Canada, Australasia, and the Cape will be some fifteen millions, nearly half what the total population of the United Kingdom is now-about equal to what it was at the date of Waterloo.

Before, therefore, the Naval Cadet of to-day is an Admirnl; before the Sandhurst Cadet of to.day is a General Officer Commanding, Colonial population will form numerically a very substantial proportion of British war resources, and probably be superior in quality to that likely then to be furnished by the mother-country. 'T'he true value and arailability, therefore, of this element of national war streugth lies-as regards these Colonies-more in the immediate future than in the actual present; but, fornsmuch as it takes at least a whole generation to build up a national, naval, or military organization, it is full time now to begin to lay the foundation of such a truly national system as shall embrace all the products of these British derelopments, and hare for its object the welding together of the elements of English war strength into "one harmonious whole." It appears to me that a system which now does not do so, must, in a generation, be discarded as effete and obsolete, or remain-to produce gradual but certain disintegration of English war-power by excluding from its original sources of naval and military strength the more vigorous portions of our race.

Questions concerning the raw materials of war resources, offered by the subiect races in Canada and at the Cape, should properly here be considered. It is, however, too special a sulject to introduce incidentally. Such resonrces, whatever their true value, must ever be secondary to those furnished by British blood. Those at the Cape can only be fairly estimated whon the present war is closed. In Canada the proportion of native races to British is very small, but, it may bo fitting here to quote from an Address to the Queen from the Clicefs of the Six Nations, "assembled at their council fire," during the Crimenn War. "Great Miotlier," they wrote, "your children of "the Six Nations have always been faitluful and active allies of your "Crown, and the ancestors of your Red children never failed to assist " in the battles of your illustrious ancestors."

On the general questions relatire to the Imperial arailability of military resources furnished by native popalations, I would venture to remark that the trath-as it generally does-would appear to lic between two extreme opininns. The one which describes a contingent of Her Majesty's Nativo troops commanded by distinguished British officers as a " horde of savages" is not worthy of scientific consideration, but the other extreme of opinion may become a source of real danger. It appears to bo briefly this : that "Home defence" is one thing, and "Imperial defence " another; that so long as British pockets are full, a sufficiency of " billets for bullets" on distant battlefields can alwass be readily procured, and may be chiefly furnished by

1 See papers presented to Parliament, 25th January, 1855. 
the bodies of British subjects having a darker coloured skin. But if the teachings of history are to be trusted, this peace philosophy, based upon the Eandy foundations of money and subject races will not, in. time of trouble, avail us much. The signal at Trafalgar was surely not of momentary import, but for all time the Slibboleth of safety of England and her Colonies alike.

Table II shows approximately the distribution or population in Plas. tation Colonies. It will be seen that the war resources offered by white popnlation are of little numerical practical ralue. Climatic and other influences combine to render it improbable that this element can ever be in this particular respect of much account.

Table III gives similar information concerning military and trading settlements, to which the same remark applies generally with greater force. These tables will bo, however, referred to later.

\section{Raw Resounces, Matracal.}

Out of innumerable materials necessary for Naral and Mrilitary purposes, it may here suffice to select three: Food, Coal, and Horses.

\section{Foop.}

It must bo remembercd we are now considering Colonial Naral and Military resources as component parts of one great whole, of which the United Kingdom is the citadel. It is, therefore, of great naral and military importance to understand how that citadel is prorisioned, and how far Colonial resources are capable of supplying its wants. According to the elaborate calcalations of Mrr. S. Bourne it appears "that out of thirty-three million inhabitants of the United "Kingdom, eighteen millions may bo sustained on food grown at "home, and fifteen millious on that received from abroad." $\mathrm{He}$ further points out "on an arernge, each member of the community "now consumes to the value of two and a half times as much forcign "food as he did twenty years back."

It is just ten years ago since in two lectures ${ }^{2}$ here $I$ endearoured to show the extreme danger of limiting the military scope of National Defence simply to these islands. The aim of those papers was to draw attention to a disagreeable, and then most unpopular. truth, viz., that military arrangements for even a passive defence conld not be confined to the simple question of inrasion, because without military aid abrond for our tleets to rest upon, the safety of our water roads was imperilled, and unless theso commnnications were secured absolutely, we conld be-starred out. The defence of our Imperial communications, be it remembered, is not a parely Naval question, but a rery complex

1 Tide paper read before the Manchester Statistical Socicty, "On the Increasing "Dependence of this Country on Foreign Supplies of Food." B5 Mr. S. Bourue, F.S.S., 1877.

2 "Distribution of our War Forces," Journal, rol. xiii, Ko. 53. 
problem inrolving a great variety of Naval and purely Mrilitary considerations. ${ }^{1}$ The national necessity for no longer delaying to deal with it is increasing with marrellous rapidity. At tho date, 1869, these papers here referred to were read, the value of the chief articles of food per head of populntion imported was at the rate of 37 shillings and five pence per annum, whilo by 1877 , it had risen gradually to 57 silitlings and seven pence. 2 The food required by fifteen thirty-thircts of our home population at present comes from rarious conntries of the Torld; consequently we have a great variety of dirergent supply lines. Our Imperial connecting lines must be defended irrespectire of all other considerations, and if our Colonies possessed food resources requisite to supply home wants, our food lines and our Imperial lines could, in war, become identical. So far, therefore, as the netual sustentation of our people at home is concerned, this rould be equivalent to an increase of war strength; hence the close connection between Colonial food and Naval and Military resources.

Table IV illnstrntes the imports of food into the United Kingdom in 1877. It sufficiently exhibits the truth that we are not, as regards food, a self-supporting Empirc. This is a great naval and military fact, and one on which the whole question of $n$ real national policy of defence turns. It would be impossible here to push inquiry below the figures of that Table, but in order to explain its illustrative importance, brief further remarks may bo useful.

Taking whent, for example, we imported during 1877 fifty-four and a quarter million odd hundredueights. Of this, some forty-four and three quarter million hundredueights came from some fifteen different Foreign Countries, ${ }^{3}$ but nine and a half million hundred weights camo from our own possessions. Of this nino and $\Omega$ half millions, some six millions came from India, and three and a half millions from the Colonies. It is to be observed that of the total wheat required by these two Islands in 1877, only about one-ninth came from Indiaprobably less through the Suez Canal--nnd only about one-serenteenth of the whole was furnished by the Colonies. We had, daring that Jear, some eighteen different wheat supply lines, made up as follows : fifteen from Foreign Countries, one from India, one from Canada, and one from Australasia.4 The great bulk, therefore, of the staple articlo of our food travelled in 1877 along lines by no means identical with the connecting lines of our Empire. The food-producing resources of the Colonies are consequently of great naval and military importance.

1 If the Naral Prizo Essay, 1878, Captain P. H. Colomb, R.N., Journal, rol. xxii, No. 94, be read in conjunction with "Strategie Harbours," General Collinson, R.E., Journal, rol. xriil, No. 77, and Pasles's "Military Polics and Institution of the "British Empire," 1808, the complexity and grarity of the question $\pi$ ill be fully understookl.

2 Fide Report of the Chief of the Bureau of Statistics, for quarter cnding June 30th, 1878. Ofticial: Washington.

3 A bout $21 \frac{1}{2}$ million crts. came from the United States, and $10 \frac{1}{4}$ million erits. from Russia-two-thirds of it from Northern ports.

4 About 6 million cwt. from India.

$\begin{array}{lll}3 & = & \text { Canada. } \\ \frac{1}{2} & & \end{array}$


What they are it is uninecessary, perhaps, to remind you. Travellers in Canada, Australasia, or the Cape see one common thing, they have bat one tale to tell, unlimited food-producing resources belonging to the English race-lying waste. One of the inestimable naral and military benefits certain to arise from a natural redistribution of British populations-within the limits of their own Empire-is therefore briefly this, a dimination in the fntare of the number of food lines absolutely requiring protection in war. The value and availability, howerer, of Colonial food resources-inexhanstible though they belies, as a naral and military question, more in the future than in the present. They will increase relatively with the first element of war strength-population. ${ }^{1}$

\section{Co.t.}

As a preface to remarks on Colonial coal, it is proper to say that they are necessnrily cursory and confined to an infinitesimal portion of a great subject. Hence it is that no mention is made of some prodigions deposits, some recently discorered, ot hers not ret much worked, in several Colonies. This paper is simply illustrative; closer and more adequate examination would directly concern Colonies not here mentioned, but nevertheless possessing such mealth."2

Coal is not merely a naval resource. Combinations and concentrations of our purely military forces are helplessly dependent on its supply. Beforo English soldiers could cross the Prah, for example, they had to cross the sea; and this preliminary movement of a small military expedition caused a variation in the export of British coal. The King of Coomassie was probably nut aware that a light applied by eren one unarmed man to a black mass at a distant Portugueso island would do more to delay the advance of his enemies than the muster at home of all his military hosts; nor did $\mathrm{Znlu}$ chieftrins at Rorke's Drift know that the time of attack of a reinforced British Army might be more or less directly influeneed by the coal-carrying capacity and conl consumption of ships selected as transports, or the quantity of fuel stored, and coaling arrangements at that same remote island of St. Vincent. Savages cannot be expected to know these things, but the English execntive, Home and Colonial, will for once make a mistake if it expects the Mioltkes or Todlebens of future wars to possess-in this matter-only the military intelligence of savages. The close connection between coal and our militnry morements is sufficiently indicated by the fact that in 1872 our export of coal to Madeira was less than 36,000 tons, to Cape Const Castle 42 tons; while the year of the expedition, 1873, it iras to Madeira over 46,000

${ }^{1}$ A great rariety of interesting and instructive matter, particularly concerning Plantation Colonies and military and trading settlements is necessarily left untouehed for want of space.

"A rery excellent paper "On the natural Distribution of Coal throughout the "British Empire," was read before the Rosal Colonial Institute by the late Mr. Eddy, 1872. Though the interral of time elapsed since it was read has altered the complexion of somo of the facts, it is still, nerertheless, a raluable guide to a studj of the subject. 
tons, to Cape Coast Castle orer 3,600 tons. If, then, the sending abroad during a time of profound naval peace of a small, compact military force-to punish a barbarous king-involved a variation of distribution of some 14,000 tons of British coal, how great will be the strnin on our power of protecting and furnishing coal supplies and coal transport from England when at war with a first-class, and perhaps, attacking power! Colonial coal resourees will then afford the only means of escape from an unworkable centralisation system on a lugge scale. According as we have in peace ntilised, developed, and prepared to grard them, so shall our Empire in war win the reward of intelligent forethought, or reap the bitter consequences of a stupid nerlect.

Turn to the Dominion of Canada, with the Aretic Regions in its rear, and along the whole length of its front a power of infinite resources. The United States at the commencement of this century had a white popnlation one-third less than the present aggregate of our Colonies Proper. Its present population now exceeds the nggregate of the United Kingdom and these Colonies together, and it is now the second maritime Power in the world. It is, for naval and military purposes, homogeneous, for its central Government can draw on and immediately apply every element of war-power found under its flag. Its left flank rests on the Pacific, and could be turned by sea from the province of British Columbia; its right flank, resting on the Atlantic, could be turned by sea from the province of Nova Scotia, and in its rear are the British West Indies. The combined naval and military operation of tnrning either flank, or attacking its rear, would primarily be a question of coal, and it is in these two provinces the Great Dominion finds its chief supply.1 It wonld be impossible to enter into any examination here of the relative qualities of coal in the several Colonies or parts of Colonies. These points will no donbt be dealt with in the disenssion which is to follow. I should, howerer, mention that space compels me merely to touch apon Colonial conl actually used now in any quantity by steamers on the sea. San Francisco steamers are largely supplied from Britisl Columbia, whilo Nora Scotia furnishes some of our own steam lines, the "Allan" for example-with coal, besides exporting it to the States. I now ask yon to cross, in imagination, by the Fijis from British Columbia to Australia; passing by Queensland-with its great coal deposits awaiting the honr of their full development-we arrive at Sydney. We are now in a Colony possessing a coal area of some 24,000 square miles in extent. At Nerrcastle, 75 miles up the coast, colliers trill be found loading for various parts of the world. At San Francisco, Hong Kong, Singapore, and Galle, \&c., their cargocs will be landed, and mingle with the coal of the mother-country, thas completing the black girdle with which British industry encircles the world. These laden vessels will, in war, be valuable prizes for hostile cruisers, and they will then require either armaments or escorts; still

1 Large coal deposits hare recently been discorered in the North West Territorj, near the line proposed for the Pacific Railray which would connect Halifax with Esquimalt. 
more will it be necessary to guard the sources of coal supply, and to arm and garrison those British points where coal is stored. Onr Colonies, with their mother-country depending on the agency of coal for nearly all that makes them prosperous in peace, may fairly share with her-in just proportion-the honour and duty of its protection in war. Neither can hope successfully to secure its safety without painstaking preparation during peace. The mother-country cannot justly chide her children for heedless disregard, natural to youth, of a duty which she in her age neglects-as testified by uuprotected British coal heaps scattered about the world. Time forbids special reference to other Australasian conl resonrces, such, for example, as those of Victoria, Tasmania, \&c., or those of New Zealand, offering as they do, pledges of that "great maritime future," of which Sir Julius Vogel so eloquently speaks. Passing on our homeward way by the Mauritius to the Cape, we find a vast British territory, the mineral resourees of which have not jet been so fully investigated as to warrant practical Naval and Mrilitary conclusions. We cannot, therefore, stop to inquire about the coal deposits in the Stromberg Mountains, Cape Colony; the Highveldt of the Transvaal, or at Biggarsherg, Natal. It is, however, at the present time, fitting to remark that our comrades advancing northward into the heart of Zululand are carrying the banner of St. George towards the Zambesi coal discovered by Livingstone. In our Plantation Colonies, there is no coal of present Naval and Military value. Some, however, of these places like Military and Trading Settlements, are of immense Imperial importance as store supply depôts. Some particulars as to the rapid increase of British coal exports will be seen in Table $\nabla$. To conclude this rude outline of Colonial coal resources, it may be observed that their Naval and Military value as regards Canada and Australasia lies in the present, and as regards the Cape, in a possible future. Canada and Australasia furnish the British race with the means of providing for its Naral and Military wants now-and in the fature-in regions most remote from home supplies. How far we avail ourselves of them for Naval and Military purposes is altogether another question. To what extent we are preparing to make our war fleets-or the links in the distant chain of our Imperial communications on which those fleets must rest-depend on these natural sources of supply, are matters upon which I shall not now enter; bat instead will conclude with two slight illustrations.

So far back as 1877 , MIr. Donald Currie in his lecture? here, forewarned the country what might happen in a European war, through the absence of a submarino telegraph to the Cape. At this moment a savage, without even a big boat, has given the "greatest maritime " nation in the world" a small taste of the consequence of neglecting such practical views as were then put forth bJ $\mathrm{Mr}$. Currie. Now it is from that lecture I extract the following pregnant sentence. "It was

1 Labuan is an exception, but so many questions of detail would phare to bo raised concerning Labuan coal, that, in dealing with great prineiples, it seemed wiser to defer remarks.

Journal, rol. xri, No. 89. 


\section{THE NAVAL AND MILITARY RESOURCES OF THE COLONIES.}

" only a short time ago that the Admiralty inquired how much coal "wo could spare at the Cape, and whether our fleet could be supplied "there, and it was impossible for the Government to Iearn in less "than fifty days their exact position." This, then, is one picture; in the foreground a Gorernment in a seren weeks' ignorance as to the power of locomotion of the National Fleet; and in the far distance, that fleet-in waters of Imperial strategic importance, ${ }^{1}$ trusting to a combination of luck and private surplus stores for its conl.

To look at the picture in another light, it is necessary to remember what MIr. Robinson, M[ember of the Natal Legislature, said in this theatre: "There exists in the part of South Africa to which I belong, " as fine a ficld of steam coal as exists in any part of the world. "That coal-field is 180 miles from the const, and we are only too "anxious to get communication by railway, but, unfortunately, our " porerty and our smallness bar the way. If the Home Gorernment "would co-operate with us to connect that coal-field with the sea, it "would open out to the British Empire a permanent and good supply " of stenm-conl.",

In speaking from this place tro jears ngo, ${ }^{3} \mathrm{I}$ drew particular notice to the defenceless state of our conl depôt at Hong Kong. Since that timo circumstances drew special attention to that part of the world. Fngland woke up thinking a war was close, and hasty preparations were made. Through the indefatigable exertions of two Officers, ${ }^{*}$ defensive works were erected in an incredibly short space of time for the protection of this particular coal depôt. I am neither aware as to whether these works are sufficiently armed, nor whether the artillery force was sufficient to man thom, but it is desirable to point out that Hong Kong is only one of a certain number of strategically placed Imperial coal depôts essential to our naral and military power of defence. In tho same paper this sentence occurs: "If war breals out to-morrow, it would " find our fleets without any system by which their supply of coal " would be assured." I venture to repeat those words again, and do so with the more confidence, because in this very theatre one year afterwards they were fortuitously, yet insolutely, corroborated by the distinguished Admiral who, at the time these words were spoken, was commanding the British feet in the quarter of the world to which they referred. Last jear, Admiral RJder incidentally said: "I hare just "returned from the command on the Japan and China station, and " with an imminent prospect of war, I felt rery doubtful whether I " should ever get a pound of coal without taking it forcibly from a "nentril."s

Now my other illustration is this : During the jear an Admiral " in

The totul commerce passing round the Cape, estimated by Lord Carnarron at $£ 160,000,000$ per annum.

2 Vide Journal, rol. xxi, No. 69, p. 241. Note. At Camdeboo, some 50 miles from Port Elizabeth, there is also cual of good quality.

3 "Russian Derelopment, and our Naral and Mrilitary Position in the Forth "Pacific" Journal, vol. xxi, No. 91.

t Colonel W. G. Stuart, R.E., and Assistant Conmissarg-General MLoore.

5 Vide Journal, rol. $\leq x i 1$, No. 97, p. 781. "Diseussion on the Prize and other "Naral Essags of 1878." 
" command" of a British fleet, in Chinese waters, "with an imminent "prospect of war," was doubtful as to getting a pound of coal, - the total export of coal from Canada and Australia excceded a million tons, and at Nerrcastle, New South Wales, hydraulic appliances for rapidly shipping coal had been established at a cost of some $£ 25,000$ to the Colony.

Some further information respecting exports of British coal will be found in Table VI, and in conclusion I would commend to your special attention the following brief extract from a work called "Coal. "Its History and Uses." By Professor Green. Miall, Thorpe, Rüker, and Marshall. "This country's fortunes," they say, "are gradually "being merged in those of a greater Britain, which, largely through the " aid of the coal whose prospective loss we are lamenting, has grown "boyond the limits of these islands to overspread the vastest and richest "regions of the earth."

\section{Honses.}

Turning from the agency on which war combinations over sea depend, meaus of transport for land operations naturally suggests itself for consideration.

It is fitting first to remind you that the prize of 5,000 roubles offered by the Czar, for the best "History of Caralry from the carliest times," was gallantly won by Canada, in the person of Lieutenant-Colonel George T. Dennison, Commanding the Governor-General's Body Guard, author of "A Treatise on Moderm Cavalry," and spoken of in Lieutenant-General Sir Selby Smyth's Official Report as one "among many "excellent Caralry Officers of the Dominion.

The war resources of the Colonies in "Horses" is, I think, a question of immense importance. Armies in Europe aro growing nlmost faster than horses fit for service are bred, and the number of horses required for war parposes increase in direct ratio to force to be placed in the ficld. A declaration of war is not exactly the time for a nation to be running about seeking horses for its guns, cavalry, and transport. It is all very well for us to rely on free-trade for our profits, and the supply of our national wants in peace; but when rumours of war are in the air, the Continental horse-market becomes, somehow or other, uncommonly "tight."

I remember, at one of our "Autumn Mancurres," watching a regimental transport man struggling with a certain ugly pair of grey brutes, exhibiting a marked objection to a certain hill. There was no mistaking the nationality of the horses; nor was there much difficulty in determining that of the man, for between the rigorous strokes of

1 The wealth of iron and other minerals of the Colonies is a great naral and military resouree. Where iron and coal are found together in large quantitics, as in New South Wales and the prorince of Nora Scotia or British Columbia and in other Colonies, the raw materinl resourees of war are enormous. It was impossible, how. ever, in a slort paper to treat of these and many other interesting fields of inquiry. The inestimable benefit sure to arise from the attraction of population from the one old part of the Empire to many ner brauches of it, is tho derelopment of these material resources here left untouched. 
his whip.-this, - free from adjectives,-was his refrain: "Ye don't "even speak English, je brates, Je don't!"

Now Table VII exhibits a fact-which naturally recurred to my memory then- that there are, in other Englands beyond sen, some tro million horses more or less accustomed to English ways, an English tongue, and an English hand. This may appear a theoretical mode of introducing a subject of great gravity, and may seem to infer obliviousness to great sea distances, and the effect on horses of long royages: in short, to lack the possibility of practical application. I hope, howerer, that, on reflection, it may not so appear. It was impossible here to inquire into the merits and demerits of various Colonial coal; and, for the same reason, the characteristics of Colonial horses can form no portion of these remarks. It will, howerer, be of profit to this Institution-and, through it, to tho Service-if the discussion elicits informa. tion on these points from gentlemen of practical Colonial experience.

The first general consideration as to horse resour'ces of the Colonies is one of numbers; this, for purposes of illastration, is met by Table VII. It is to be borne in mind, however, that the same obserration made respecting the extent of area covered by population applies, though perhaps in a more limitcd degree, to the "raw material" of war furnished by horses. An example of this trath was indirectly afforded by H.R.H. the Duke of Cambridge with reference to the despatch of horses to the Cape. In the House of Lords, H.R.H. said: "The "reason was obrious. To collect a large number of horses on the "spot would take time, and it was necessary that the men should go " ready to take the field on landing."

The next general reflection is that as our Colonial Empire contains rast territory in every clime-from the frosty $N$.W. Province of Canada to the tropical districts in Northern Australia,- - so are to be found within its limits, horses naturally suited to the purposes of war in any part of the world where British forces may have to operate. I may mention that in Queensland five shillings per head has been sometimes paid for shooting wild horses, in order to clear the " Runs" and to prevent interference with the domesticated animals.

Now as regards sea distances, which is the point on which the practical question of value and arailability turns. No student of modern warfare can observe the increasing facilities of transporting live nnimals in large numbers over long sea distances-which have been created by the push and shove rivalry of peaceful commercial competition-without reflecting how means so afforded can be turned to account in war. To my mind, they furnish to us at once a warning and an encouragement. A warning, because they show that long sea distances do not in themselves present insurmoutable obstacles to forcign attack: an encouragement, because we have only to prepare to avail ourselves of the experiences of peace and to consolidate the Imperial resources we possess-to render our Imperial position at all points practically secure. As a matter of fact the military obstacles

1 The number of horses, returned by occupiers of land, in the United Kingdom, 1878, was 1,927,066. Vide Agricultural Returns, 1878.

2 Sce Debate in the House of Lords, 21st February. 
apparently presented by long sea distances-in the matter of horsesare theoretical obstacles imagined in peace, which, with good management and arrangement, vanish under pressure of war. In peace, large numbers of Australian horses, and no inconsiderable number of Cape horses, find their way to India and some time ago, British Columbia frequently imported horses from the Saudwich Isles, a distance of some 2,400 miles. The Mrutiny in India compelled our establishment there to draw largely on Australia for horses, and the bustle of their embarkation at great ports like Melbourne and Sydney told the tale of Military requirements of war capable of fulfilment from points 5,000 miles distant. Recent events in one corner of the world caused a native cavalry force to be moved from India to Malta. Across 4,000 miles of sea it came, showing Englishmen - Home and Colonial-that steam has bridged not only the Channel, but the water distances which separate the various portions of our Empire from the mother-country and from each other; and reminding all, that Empire is not merely something " to be enjojed" in peace, but that it has to be "maintained" by force in war. Again, cavalry, which, six weeks ago was at Hounslow and at Aldershot, is now across the Tugela, 6,000 miles away, thus completing a practical illustration of possible reciprocity of duty and obligation between England and her Colonies. If we can go to them, they can come to us.

It must be remembered, howerer, that we are now regarding horses as "raw material" of war-power; the "charger" or "battery "horse" is a dereloped material. The certain change from one to the other is but a matter of time and skill, accomplished by forethought and resulting from care, and therefore these short notes under this head may, I think, be thas summed up. The ralue of military resources of the Colonies, as regards horses, lies in the present, and their availability depends upon the nature and extent of arrangements made in peace, by which alone they can, in war, be torned to organized aud instant account.

While we remember that caralry las been rapidly moved from England to the Cape, and swiftly from Bombay to Malta, let us not forget that there are in Canada, for example, nearly a million horses and "many excellent cavalry Officers;" that Ottawa is nearer Constantinople than London is to Pietermaritzburg, and that Bombay is farther from Malta than Malta is from Halifax.

It is now timo to close this rude surrey of those "raw materials"

1 In adrocating the appointment of a Royal Commission to inquire into the question of Imperial defence, the writer of this paper, speaking in 18\%3 (of the reciprocity of duties and obligations between England and the Colonies, and of the common duty of strengthening and protecting the points which command the Imperial road), made use of the following words to conrey a maning more jractically exemplified by the presence of Indian troops at Malta fire years later: "With the " ereation of Imperial fortresses commanding the Imperial roads rould grow up a "fecling of common security. They rould be links in the chain wlich binds "together the military forees of our Empire; stepping stones by which those forces "can cross to afford mutual assistance and support." Tide "Colonial Defence," Journal Rojal Colonial Institute, 1873. 
of Colonial naval and military power which appeared to me most worthy of selection for these short remarks. Whether you agree with me in the general conclusions I havo thus far attempted to indicate, or whether you do not, you will not, I hope, at all events, bo disposed to differ with the following general conclusions. That from a naval and military point of view, the application to any Imperial parpose of such outlying sourees of war-power as the Colonies possess rests practically on means of transport and the ensured safety of the sea. The Colonial Mercantile Marine may fairly claim its place, thercfore, under the head of "dereloped resources," and, with the armed strength, and naval and military organization of the several Colonies, will form the subjects for consideration in Part II of this paper.

Brief, and entirely inndequate though these references to the raw material of Colonial war-power may be, they form a necessary intro. duction to the consideration of such developed naval and military resources as the Colonies yossess. They will, I trust, not bo witlout some slight ralue. Their very insufficiency will, at all events, show that beneath the surface, over which we have so lightly passed, are yet unfathomed depths of useful study. Great as the natural advantages of England lave been in the past, great though they still be in the present, they seem but shrivelled and stunted when compared with thoso of Greater Britain. Whether the power of self-preserration derivable from such aids will, in dajs to come, split into fragments, or becomo united and consolidated, must more or less depend upon the direction of present progress. Either result will more probably be dereloped from gradual growth, rather than spring from spontaneous or sudden change. If Colonial resources, as they become arailable, are not grafted into one great defensive system for a common purpose and a common good, then our Imperial power of resistance already con. tains elements of naval and military disintegration, and lacks that unity which is strength.

I cannot, therefore, conclude this portion of $\mathrm{my}$ subject without reference to one or two facts which afford some indications of the direction of present progress, and I shall take the heads of this paper in interse order.

As regards Horses. In 1873, a Committee of the Honse of Lords inquired into the question of Horse Supplies. It was stated to the Committec, that "in case of emergency arising, the Continent would " be virtually closed to us for the purchase of horses." In reply to the 1613 question, Canada was referred to as " another country where we " could get lorses," liut which had not been mentioned. Out of 4075 questions only 33 had reference to Canada; but one witness-Colonel Jenyns-was examined as to Canadian horses. Ho stated that "they "were wonderfully good horses . . . as good troopers as he over " saw," and that "they stand a great amount of hard work and " exposure." He was asked rould ho bring them over in sailing or steam vessels. There is no mention of Canada or of any Colony in the Report. So far as I am aware, we are not in any way proparing to make ready use of the available horse resources of the Culonins on an emergency, though wo know full well we shall.want horses, and that 
we shall not get them from the Continent. The direction of present progress, therefore, does not appear to me to be encouraging.

As regards Coal. In papers presented to Parliament on Naval trials of Coal, 1877, I find it reported " that the classes of ships comprising " the larger proportion of the vessels on the China Station should not " in future be replaced by similar vessels; or that coal giving different "results should be supplied to the depotts on the station." Now the British coal most readily obtainable on that station and on the South Pacific and Indian Ocean, is Australian. Can anyone say which is the principle of our Naral policy - whether coal is to be adapted to the ships for serrice on these stations, or the ships to the coal? Is A Iahomet to go to the mountain, or the mountain to Mahomet? Until that question is fairly and practically answered, it is hard to say-as regards coalin which direction Naval progress lies. If, without regard to the nature of British coal found on certain stations, we despatch vessels and fleets with arrangements not adapted to produce maximum results with any other than Home coal, we are not making proper use of our arailable Naval Colonial resources, and are endeavouring to carry on the defence of an Empire with resources found only in one small corner of it. The question of boiler and furnnce arrangements determines a far wider one, viz., whether we are to drag coal across the world to our fleets or to draw on British resources close at hand. But that is not all. Aro we to suppose that because Australian conl does not give equally good results as TVelsh coal-in our present ships, that the question ends there? Is Australia to have no Naval future because her coal does not exactly suit the war vessels the mother-country chooses to construct to-day? Act as we may, Australia will grow, flourish and develop, and if we do not now begin to realize the adrantage of dovetailing our Naval system into her arailable resources, when are we to begin? Trun to Table V, which shows that since the Crimean War, the export of coal from one Colony has risen from 60,000 tons in a year to nearly one million. Onr children now may live to see the annual export of coal from Australia exceed that from the mother-conntry. Whose business will it be then to protect that supply in war? Will it bo England's or Australin's, or our Empire's? The answer to such a grave question can only be dimly discorned through the mists of present Naval progress.

It is to be noted that (as will bo seen by Table VI), not quite three million tons of British coal mere exported in 1877 to British Ports abrond, while over thirteen million tons went to Foreign Ports. We have every advantage as regards geographical positions for storing coal afforded by our Plantation Colonies in the West Indies. It is an important fact that out of some 475,000 tons of British coal exported to that quarter of the world in 1877, but 172,000 tons went to the British, while the rest went to the Foreign West Indies. Had war broken out in that year, our enemics would, in that district of the world, hare had greater facilities of coal supply than our vessels. In the matter of coal, and as regards these Colonies, our progress tends to throw the balance of naval power from them towards ports that in war will be neutral.

VOL. XXIII. 
As regards food. Most Officers must, I think, have found that naval, military, and marine pensioners are every day finding it more and more difficalt to provide at home for themselves and their families. Their families have, as a rale, been brought up in an atmosphere of order, eleanliness, and discipline, and benefited largely by education at the expense of the State. Take these facts into consideration, together with the waste of food-prodncing resources, and the manifest desirability of fostering cordial feelings in the Colonies towards the British seaman and soldier, and reflect that while we are at our wits' end to provide inducements to serve in the Army and Navy, the word Colonies, as suggesting a means to an end, is never even whispered. Russia, as an inducement to her seamen to settle at Vladivostok, moves their wives and families free of expense from one side of the world to the other, and can we with our magnificent territories do for our seamen's and soldiers' families- nothing? It is important to remember that eren now in the great English continent of Australia wondering English children listen to their mothers' description of British soldiers once seen by her there, and that is all the next Australian generation will really know about them.

In conclusion, and as directly bearing on the food question in its wider aspects, I commend to earnest attention the following short extract from the proceedings of "The Irords' Committee" on Horses. Referring to the incidental allusion to Canada by Sir H. Storksa sort of official right-hand of the War Mfinister of England-the following question was put to him, and the following answer given. Question: "In the event of a war with France or any other great "Naval Power our importation of horses would nat nrally be interfered " with, and that would be a great difficulty, wonld it not ? Answer: Yes; "certainly.." Now if the importation from Canada of a few thousand lorses, will when at war with a great Naval Power "naturally be in"terfered vith," what is to become of the fifteen thirty-thirds of our home population dependent on eighteen different lines for their food? 